\title{
PANORAMA KONSTANTYNOPOLA W LIBER CHRONICARUM HARTMANNA SCHEDLA (1493). MIASTO IDEALNE - MEMORIA CHRZEŚCIJAŃSTWA
}

1. Wstęp. Hermeneutyka obrazu, którą proponujemy w niniejszej pracy jest rozpięta pomiędzy „obrazem” a „obrazem”, bowiem dotyczy widoku Konstantynopola w Kronice Hartmanna Schedla (1440-1514), która została opatrzona obszernymi badaniami historycznymi, ale nadal jej kontekst geneza i funkcja pozostają otwarte ${ }^{1}$. Wyczerpujące badania historyczne Wernera Kreuera wraz z faksymilowym wydaniem wszystkich drzeworytów pozostaną na obecnym stanie badań najbardziej autorytatywnym opracowaniem naukowym ${ }^{2}$. Szczegółowo analizowane są rozpoznania budowli, opatrzone obszernym komentarzem historycznym, który dotyczy wszystkich widoków zamieszczonych miast. Ukazana jest obszerna historia przemian politycznych i religijnych, zostały wskazane źródła wiedzy historycznej, z której czerpał autor tego monumentalnego dzieła. Na tym studium został oparty podstawowy opis widoku Konstantynopola w niniejszej pracy, jak również rozpoznanie topograficzne miasta i jego budowli. Plan 1 - w istniejących badaniach wskazuje się na cechy ogólne i charakterystyczne dla konkretnych widoków ponad setki drzeworytów miast. Rozpoznaje się ich budowle konkretne oraz umowne, miejsca zarówno rzeczywiste, jak i umowne czy wręcz nierealne. Zasada wspólna wszystkich widoków dotyczy murów obronnych zamykających obwód miast, poza którymi zaznaczono wzgórza, wysokie szczyty z zamkami i warowniami. W obrębie murów występuje gęsta zabudowa $z$ licznymi wieżami analogicznymi lub identycznymi w wielu widokach miast. Wyróżnione zostały także cechy indywidualne, charakterystyczne dla konkretnych widoków,

* Prof. dr hab. Urszula Mazurczak - profesor zwyczajny w Katedrze Historii Sztuki Średniowiecznej i Nowożytnej w Instytucie Historii Sztuki na Wydziale Nauk Humanistycznych Katolickiego Uniwersytetu Lubelskiego Jana Pawła II; e-mail: ursmaz@kul.pl.

${ }^{1}$ Por. E. Rucker, Die Schedelsche Weltchronik das grosste Buchunternehmen der Durer - Zeit, München 1988; A. Berger - J. Bardill, The Representations of Constantinople in Hartmann Schedel's World Chronicle, and Related Pictures, „Byzantine and Modern Greek Studies” 22 (1998) 3-29.

${ }^{2}$ Por. W. Kreuer, Imago civitatis: Stadtbildsprache des Spätmittelalters: Essener Bearbeitung der authentischen Stadtansichten aus der Schedelschen Weltchronik von 1493 mit 32 Vollfaksimilierungen des Orginals [sic] der Diözesan- und Dombibliothek Köln, Essener Geographische Schriften 2, Essen 1993. 
np. architektura kościołów, urządzeń miejskich m.in. papiernia w Norymberdze. Przeważają schematycznie wyrysowane budowle zamknięte pierścieniem murów, wskazują na posługiwanie się prototypami wzornikowych panoram ${ }^{3}$.

W niniejszych rozważaniach uwaga jest skoncentrowana na widoku Konstantynopola, którego budowle zostały już rozpoznane w badaniach naukowych, acz pytania i wątpliwości nadal stanowią podłoże wielu dyskusji. Nowe odkrycia archeologiczne, źródłowe i historyczne, modyfikują wprowadzone rozwiązania. Ten kierunek badań pozostawiamy kompetentnym badaczom. Dla nas interesującym zagadnieniem jest spojrzenie na panoramę Konstantynopola (która należy do wielkiej grupy obrazów umieszczonych w Kronice), w kontekście historii wyobrażania miast w sztuce europejskiej. Zwrócona jest również uwaga na wpływ tekstów o miastach, które powstawały w literaturze średniowiecznej. Widoki miast przekazane w plastyce: malarstwie, reliefach, również w wyobrażeniach antycznych, koncentrują badania na pytaniu o realia architektoniczne ukazane $\mathrm{w}$ widokach miast. Nie pomija się zagadnienia czysto estetycznego oraz związku z pisanymi na cześć miast tekstami religijnymi, będącymi prośbami o opiekę Boską nad miastem ${ }^{4}$. Specyfika widoków miast zwartych w Kronice H. Schedla budzi pytania, w jakim stopniu stanowią one sumę doświadczeń wyobrażania miast $\mathrm{w}$ średniowiecznym miniatorstwie i malarstwie monumentalnym, a co je wyróżnia spośród tradycyjnych panoram miast. Wpisują się do pewnego typu wyobrażeń miast, które były kształtowane w obrębie różnego rodzaju tekstów: religijnego, biblijnego, mitologicznego, literackiej loci amoenus lub retorycznej eklogi, pieśni jako hymnicznej pochwały, jako panegiryku na cześć miasta. Rodzaj słownego przekazu był adekwatny do jego funkcji, określał również odbiorcę. Wyobrażenia miast omawianej epoki, biorąc pod uwagę bogatą tradycję antyczną, były derywatami tekstów, które określały ich kompozycje i estetyczny charakter. Funkcją obrazu miasta i konkretnych budowli była pamięć historyczna, określająca grupę lub zbiorową społeczność religijną.

W przedłożonych rozważaniach, podejmujących hermeneutykę panoramy Konstantynopola w kronice H. Schedla, chcemy wskazać na aspekty rozumienia miasta jako zbioru loci służących pamięci. Miejsc, które ożywiając przestrzeń wyobrażoną, przywracają czas, lub czas zachowują dla teraźniejszości i przyszłości. Podejmujemy próby odczytania widoku Konstantynopola (mając na uwadze przynależności do ogromnego zbioru drzeworytów w ana-

${ }^{3}$ Por. J. Białostocki, Sztuka XV wieku. Od Parlerów do Dürera, tłum. G. Przewłocki, red. naukowa, aktualizacja i uzupełnienie bibliograficzne A. Ziemba, Warszawa 2010, 215.

${ }^{4}$ Por. D. Peil, Untersuchungen zur Staats- und Herrschaftsmetaphorik in literarischen Zeugnissen von der Antike bis zur Gegenwart, München 1983; Imago urbis. L'immagine della città nella storia d'Italia. Atti del convegno internazionale (Bologna 5-7 settembre 2001), a cura di F. Bocchi - R. Smurra, Bologna 2003; U. Mazurczak, Miasto w pejzażu malarskim XV wieku: Niderlandy, Lublin 2004; Ch. Frugoni, A Distant City. Images of Urban Experience in the Medieval World, Princeton 2008 (z obszerną bibliografia); A.M. Orselli, Tempo citta e simbolo fra tardoantico e alto medioevo, Bologna 2009. 
logiczny sposób ukazanych miast w Europie), będącego dokumentem historycznej antropologii konkretnych miejsc: kościołów, pałaców, murów, bram miejskich, kolumn, monumentów ukazanych w specyficznej sytuacji politycznej tego miasta. Liber chronicarum zostało opracowane przez H. Schedla w seriach drzeworytów opatrzonych opisami, a wydane w roku 1493 . W obrębie drzeworytów, panoramy Konstantynopola zostały przekazane na fol. $129 \mathrm{v}$ i $130 \mathrm{r}$ oraz na $290 \mathrm{r}$, w tym ostatnim przypadku Konstantynopol został błędnie podpisany jako „Italia”, co poprawione zostało w wersji niemieckiej. ${ }^{5}$ Tekst przekazuje informacje historyczne dotyczące powstania panowania władców, fundacji budowli, ekonomicznej prosperity.

Rok 1493 wydania drukiem Kroniki świata wpisuje się w określony czas historyczny i określoną epokę w kategoriach duchowości, nazwanej Geistesgeschichte, implikującej związki międzyludzkie osobowe, kultury materialnej i stricte duchowej. Była to epoka przełomu czasów średniowiecza i nowożytności, wczesnego kapitalizmu Norymbergi. Wtedy to następowała ekspansja dzieł wydawanych drukiem, tym samym drzeworytnicznych ilustracji mogących być powielanymi w identycznej formie w „nieskończonej” liczbie egzemplarzy. Dzieło powstało w kręgu osób reprezentujących różne zawody, dzisiaj nazwalibyśmy artes liberales i nauk ścisłych, wiedzy technicznej oraz nauk medycznych, prawniczych, a także wysoko wyspecjalizowanych rzemiosł. Określało to w sposób szczególny wspólnotę ówczesnej Norymbergi z jej wczesnym humanizmem, potrzebą nasycenia się wytworami sztuki, a zarazem aspiracjami, jakie niósł wyraźny kształt kapitalizmu. Kronika H. Schedla obejmuje 1809 drzeworytów (razem), więc stanowi tym samym najbogatsze dzieło księgi drukowanej nie tylko w Niemczech, lecz także w całej Europie. Drukiem zajmował się drukarz Anton Koberger, natomiast mistrzem ilustracji był Hartmann Schedel, z zawodu lekarz o szerokich horyzontach humanistycznych i pogłębionym wykształceniu. Łączył wiedzę z miłością, np. do kolekcjonowania kodeksów i ksiąg drukowanych, tworząc w ten sposób prywatną bibliotekę, a jego zbiory stanowią dzisiaj podstawowy zbiór Bayerische Staatsbibliothek ${ }^{6}$. Kroniki świata pod względem tekstu oraz ilustracji potwierdzają spójność, stanowią jedyny tak obszerny zbiór opisów i obrazów: postaci, wydarzeń biblijnych, mitologicznych greckich, rzymskich, historii chrześcijańskiej i najnowszej autorom. Stanowią średniowieczną summę wiedzy zilustrowanej o świecie, o jego powstaniu, początkach, przemianach i przełomowych zdarzeniach, a nade wszystko widokach miast ówczesnej Europy. Biblijna historia splata się ze współczesnością i była cytowana przez

${ }^{5}$ Por. Rucker, Die Schedelsche Weltchronik, s. 8; Berger - Bardill, The Representations of Constantinople, s. 3.

${ }^{6}$ Por. Rucker, Die Schedelsche Weltchronik, s. 6. Finansowania powstania kroniki podjął się mecenas Sebald Schereyer, który jako mistrz kościelny miał duży wpływ na powstanie kościoła św. Sebalda w Norymberdze. Protektorem dzieła był szanowany w Norymberdze rzeźbiarz Adam Kraft, znany w historii sztuki. 
współczesnych artyście, ówczesnych humanistów, tej miary co Enea Silvio Piccolomini. Przekazane zostało osobiste spojrzenie autora Kroniki na historię, naturę, na podróże, na wiedzę o człowieku, o ziemi i o kosmologii. Autor ukazał się jako średniowieczny uczony scholastyk i jako wczesnorenesansowy platonik. Potwierdził rozumienie związku tekstu i obrazu na wzór kodeksów, które gromadził, ale nadał nowego ducha w interpretacjach widoków miast, zwłaszcza natury, co należy podkreślić w tym miejscu. W wielu przypadkach ukazane miasta były pierwszymi widokami, które nie miały wcześniejszych wzorów. Jednocześnie w przyjęciu określonego typu wyobrażeniowego nawiązuje do znanych motywów miast włoskich. Podkreśla się wszak w literaturze przedmiotu, że autor tekstów i widoków zawartych w Kronice świata nie ma miał ani pierwowzorów, ani następców, którzy podjęliby się analogicznej pracy. Kronika świata H. Schedla powstała w pamiętnym roku 1493, równocześnie w wersji łacińskiej 12 czerwca, a 23 grudnia w niemieckim thumaczeniu z łaciny w norymberskim stylu językowym ${ }^{7}$.

Na wybranych przykładach miast chcemy wskazać pewne cechy, które charakteryzują przemyślaną zasadę w prezentacji tekstu i obrazu. Katalog miast jest bardzo bogaty wraz z historią oraz widokami najważniejszych dla miasta budowli. Autor opisuje przykładowo historię miasta, np. Augsburg, wskazując na pochodzenie nazwy - Augusta od cesarza Augusta, czerpiąc wiedzę z historii Strabona. Wymienił cesarzy z linii Ottonów władców niemieckich. Ponad miastem dominuje osiem wież, które przypominają współczesny H. Schedlowi widok - Bamberg miasto w Frankonii z rzeką Rednitz. Istotne jest dla autora topograficzne położenie, jednocześnie ukazał zbyt wysoką górę z zamkiem jako siedzibę cesarza Henryka II i jego żony Kunegundy ${ }^{8}$. Kolonia w historii H. Schedla pochodzi od Troi, choć styl obrazu został przejęty według modelu miasta Augsburga. H. Schedel znał dobrze Kolonię, ale mógł posłużyć się widokiem Kolonii Weinricha Quentella z roku 1480. Stworzył jednak nowy, własny widok. Miasto widziane z brzegu Renu, gdzie usytuowane są frontalnie statki na rzece oraz warsztaty budowy łodzi na rzece. Ponad murami miasta z wieloma basztami wyróżniają się swoim rzeczywistym wyglądem kościoły: St. Severin, St. Kuniberta, Brama Bawarska. W tym czasie dopiero był kończony chór katedry NMP. Ukazany widok nie ma wiele podobieństwa z rzeczywistością?.

Na uwagę naszą zasługują miasta w Polsce - Breslau, Wrocław pierwotnie zapisywany Presslau jako kraj na Śląsku. H. Schedel określa go jako kraj zamieszkany przez szlacheckie rody Teutonów i Sarmatów. Miasto położone nad rzeką Odrą, słyszy się polski język w wielu rozmowach. Opisał wszystkie najważniejsze kościoły i klasztory. Najbardziej jednak zachwyciły go mury obronne, jak napisał: „miasto jest obwiedzione pięknymi murami obronnymi

\footnotetext{
${ }^{7}$ Por. tamże, s. 15.

${ }^{8}$ Por. H. Schedel, Liber chronicarum, Nuremberg 1493, 86.

${ }^{9}$ Por. tamże, s. 95-96.
} 
z zakonnymi zabudowaniami na obwodzie" ${ }^{\prime 0}$. Mury mają cztery wieże w czterech kierunkach, dostrzegł piękne domy i ratusz z wieżą, gdzie słyszał hejnał. Nasz uczony nie mógł pominąć Krakowa, królewskiego miasta Sarmacji, którego nazwę wyprowadził od Carrodunum, według Ptolemeusza Klaudiusza, w przeciwieństwie do polskiego kronikarza Wincentego Kadłubka ${ }^{11}$. Budowle przedstawiają realia, ale całość stanowi odzwierciedlenie przyjętej idei. Wawel jest wysoką górą, dominującą symetrycznie ponad miastem z okazałym zamkiem na szczycie. Natomiast brak mieszkańców miasta w widoku obrazowym jest dopełniony w opisie. Mieszkańcy mądrzy, dworscy i dobrze odnoszący się do siebie, przyjaźnie nastawieni - dodaje jednak autor, aczkolwiek pokolenie naszych rodziców uważało ich za gruboskórnych, grubiańskich, niedelikatnych, niezaradnych i nieokrzesanych ${ }^{12}$. Wyraźnie fascynują $\mathrm{H}$. Schedla miasta Italii: Rzym, Wenecja, Genua, Florencja, Piza. Historyczne przekazy czerpał z dzieła m.in. Pliniusza. Antyczne miasto dla H. Schedla ma przede wszystkim mury obronne i bramy na wzgórzach, antyczne pamiątki, które znał jedynie $\mathrm{z}$ ruin. Wenecja, z którą Norymberga utrzymywała bezpośrednie związki handlowe, jest najsłynniejszym miastem na świecie, a mieszkańcy posiadają wszystko co jest potrzebne człowiekowi do życia ${ }^{13}$. Wskazano na inspirację wzoru widoku Wenecji według Reuwicha, choć nie można mówić o kopii. Największą rangę przypisał Jerozolimie ukazanej trzy razy, podobnie jak Konstantynopol. Autor wykorzystał znane rysunki i plany, a także opisy, co przy licznych pielgrzymkach tego czasu nie było trudne. Miasto zostało opisane jako bogate w wodę, aczkolwiek poza murami jest wielka posucha. Budowle zbudowano z kosztownych materiałów. Podkreśla znaczenie miasta w kontekście relikwii i loca sancta. Śmierć Chrystusa uświęciła to miasto, które zachowuje groby wielu zmarłych proroków Starego Testamentu. Miasto ma Górę Wniebowstapienia Chrystusa. Autor podaje dokładne wymiary świątyni: 60 łokci wynosi jej długość, 20 łokci jej szerokość. Jednak wymiary te nie odpowiadają rzeczywistości ${ }^{14}$. Bogaty przekaz wiedzy historycznej, a także drobiazgowość ukazanych rzeczy, m.in. budowli w oddaniu panoram przy jednoczesnym braku ludzi zostały przyjęte jako zasada widoków miast. Wydają się być martwymi makietami, jednak zawierają wewnętrzną antropologię historyczna, tzn. władców, założycieli i twórców. H. Schedel ceni mądrość i kulturę mieszkańców oraz twórcze umiejętności rzemieślników. Nie ukazuje ludzi, a jego antropologia miasta jest zakotwiczona głębiej jako rezultat pracy twórczej, życia religijnego, artystycznego. Sytuuje człowieka w najgłębszej istocie miast, nadając im ukryta, ale niezwykle intensywnie pulsującą tkankę duchową. $Z$ rzetelnością historyczną odkrywa historię biblijną, która jest początkiem jego wielkiej Kroniki świata.

\footnotetext{
${ }^{10}$ Tamże, s. 88.

${ }^{11}$ Por. M. Fabiański, Złoty Kraków, Kraków 2010, 69-70.

${ }^{12}$ Por. Rucker, Die Schedelsche Weltchronik, s. 89.

${ }^{13}$ Por. wyd. niemieckie: H. Schedel, Weltchronik, Nuremberg 1525, 121.

${ }^{14}$ Por. tamże, s. 116 i passim.
} 
Świadomie zostały wymienione powyżej jedynie skrótowo niektóre opisy miast, które stanowią same w sobie indywiduum, a zarazem kondensują zasadę tworzenia widoków. Już same kompozycje stanowią typologie miast o horyzontalnym układzie, któremu są poddane topograficzne cechy z charakterystycznym odsunięciem murów obronnych od linii gruntowej. Wzdłuż murów roztacza się krajobraz w kształcie pasowym rolniczych pól, łąk, rzek lub morza $\mathrm{z}$ zatoką. Zatem została wygospodarowana świadomie otwarta, wolna przestrzeń, nadająca zamkniętym obwodom dystans przestrzenny, implikujący światło i powietrze. W ten sposób widoki miast, w swojej skostniałej architektonice, zostały ożywione żywiołami: ziemi, wody, powietrza i światła, a więc czterema żywiołami określającymi życie. Panoramy zamknięte po bokach kulisami wzgórz lub ostrych szczytów z zamkami obronnymi, mimo ujednoliconej zasady widzenia, posiadają swój charakter i tym samym wymagają szerszej, odrębnej analizy szczegółowej.

Podejmujemy analizę Konstantynopola ze względu na jego wyjątkowe uwarunkowanie historyczne i sytuację. W czasie, gdy powstawała Kronika, to historia tego miasta była porównywana z początkami chrześcijaństwa, z Jerozolimą, a więc tworzyła się na nowo, w sytuacji upadku miasta w roku 1453. Powstanie miasta i założenie przez Konstantyna Wielkiego było dla $\mathrm{H}$. Schedla niemal równoważne z historią Jerozolimy, Rzymu, miast niemieckich i europejskich. Konstantynopol, wyrosły z rybackiej osady Byzantion skrytej w zatoce, był początkiem rozkrzewienia tradycji greckiej kultury, tak bardzo ożywionej w Europie w czasach H. Schedla. Schyłek średniowiecza pulsował już nowymi prądami, dla których szukano genezy, korzeni zarówno antycznych, jak i chrześcijańskich. Niniejsza praca nie pretenduje do odtworzenia lub nazywania miejsc ukazanych w widoku miasta, co jest $\mathrm{w}$ opracowaniach historycznych, nie pretenduje do rekonstrukcji zaginionej przeszłości, którą podejmują żmudne poszukiwania archeologów, nie pretenduje do komparatystyki historii materialnej, podejmowanej w studiach historycznych. Widok Konstantynopola proponujemy postrzegać w kontekście tradycji obrazowania miast w Europie średniowiecznej, głównie $\mathrm{w}$ Italii. Poszukujemy racji $\mathrm{w}$ celu porównań z ukazanymi makietami miast, pełnymi architektury, ale niezamieszkanymi, jednocześnie niebędącymi mapami. Istnieje natomiast możliwość odniesienia tego typu modeli do literackiej topiki $\mathrm{w}$ hymnach pochwalnych rozpowszechnionych $\mathrm{w}$ średniowiecznym piśmiennictwie. Chcąc przybliżyć nasz problem odwołamy się do rozpoznawanych budowli w widoku Konstantynopola, przyjmując jako autorytatywne studium W. Kreuera, wraz z faksymilowym wydaniem wszystkich ilustracji zawartych $\mathrm{w}$ oryginale oraz uznanymi $\mathrm{w}$ literaturze przedmiotu opracowaniami Elisabeth Rucker, Albrechta Bergera i Jonathana Bardillego, których stanowiska różnią się, co do niektórych budowli, $\mathrm{z}$ interpretacją W. Kreuera. 


\section{Opis i rozpoznanie najważniejszych budowli, oznaczenia literowe i zasadnicze interpretacje według W. Kreuera ${ }^{15}$.}

a) Architektura sakralna. W obrębie miasta wyodrębniony został kościół z pięcioma kopułami rozpoznany jako Kościół Pantokrator (A) kościół (Zeyrek Kilise Camii) w rzeczywistości są trzy złączone kościoły zespolone pięcioma kopułowymi wieżami, co zostało powtórzone w opisie planu Konstantynopola na planie Gabriela z 1537 r. Klasztor, do którego należał, założony przez cesarzową Irenę († 1124), kościół środkowy - kościół Jana Komnena II (1118-1143), północny kościół został ukończony w 1180 r. Wezwanie Pantokratora jest znane z życia Georgiosa Scholariosa Gennandiosa, który po zdobyciu Konstantynopola przez Mehmeta II w roku 1454, został patriarchą, a kościół w roku 1453 został przemieniony na meczet.

(B) Kościół Pammakaristos z zabudowaniami klasztornymi został ufundowany w wieku XI i XII, odnowiony w wieku XIII. W roku zdobycia miasta 1454 i do 1596 był miejscem patriarchatu. W opisie podróży z roku 1613 Reyszbeschreibunga Salmona Schweigera z Norymbergi został zarejestrowany cały kompleks, który był otoczony murem obronnym.

(C) Bazylika Armeńczyków, typowa trójnawowa bazylika, została zachowana na późniejszych widokach, jednak dzisiaj nie istnieje.

(D) Hagia Sophia (Aya Sofya Muzesi) - lokowany w południowo-wschodniej części miasta $\mathrm{z}$ hipodromem po lewej stronie i Seraglio po stronie prawej. W wydaniu planu na fol. CXXX jest określona inskrypcja jako Ecclesia Sancte Sophie w języku łacińskim, co znaczy, że jest to interpretacja dodana przez Schedla. Dominujący w panoramie miasta kościół ufundowany przez cesarza Justyniana, określony jako jedyny inskrypcją Ecclesia. Schedel opisał kościół, że jest największą budowlą na całym świecie, pośród wielu monumentalnych, znanych mu kościołów w Europie łacińskiej, które podjęły próby naśladowania tego monumentu, np. katedra Santa Maria del Fiore we Florencji. Świątynię zbudował cesarz Justynian i - jak przekazuje autor - opiekuje się nią 900 kapłanów. Jest cudowną budowlą zbudowaną z kosztownych materiałów, marmurów i półszlachetnych kamieni. Historia budowli sięga czasów cesarza Konstantyna Wielkiego. Była najważniejszą świątynią w mieście poświęconą Mądrości Bożej, gdzie była również katedrą dworską. Pierwszy kościół ukończony w 360 r. zniszczył pożar w 404 r. Obok jest zaznaczona w widoku Schedla druga, mniejsza kopułowa budowla, która służyła jako baptysterium, a w latach 1640-1648 pełniła funkcje mauzoleum sułtana.

(E) Nieco na północ tuż za kopułą Hagia Sophia jest widoczny kościół św. Ireny z kopuła, budowla była poświęcona jako Świątynia Pokoju. Po roku 1453 służyła jako magazyn wojskowy, potem było tam muzeum wojska. Krzyż zaznaczony w części absydy podkreśla rangę tego miejsca, określonego inskrypcją proroka Amosa $(9,6)$. Fragment ten odnosi się do hymnu proroka, $\mathrm{w}$ jego istotnych słowach w greckiej wersji nawiązuje do wszechmocy Boga:

\footnotetext{
${ }^{15}$ Por. Kreuer, Imago Civitatis, s. 98.
} 
„On buduje swoje wejście do nieba; On opiera na fundamentach ziemi swoje obietnice; On przyzywa do siebie wodę z morza, a potem polewa nią oblicze ziemi; Jego imię - Pan Bóg, Wszechwładca"16. Nawiązanie przez H. Schedla do proroka Amosa nie jest przypadkowym zabiegiem, z cytatem przepowiedni wszechmocy Boskiej. W przedsionku świątyni był sarkofag porfirowy z cesarskimi szczątkami, które złożono w kościele św. Apostołów, a według tradycji uchodził za sarkofag Konstantyna Wielkiego ${ }^{17}$.

(F) Kościół Sergiusza i Bakchusa, dokładnie obok murów Konstantyna w pobliżu wybrzeża Bosforu. Schedel podkreślił fundację Justyniana udokumentowaną w roku 527. Był pierwszym kościołem wybudowanym w pobliżu pałacu Hormidasa poza murami od strony morza. Budowlę ukończono w roku 536, a w 1453 r. zamieniono na meczet. Plan oktogonu pokryty kopuła jest, jak się do dzisiaj podkreśla, największym osiagnięciem architektonicznym tego typu jako „przedstudium” dla Hagia Sophia - dzieła tego samego architekta.

(G) Kościół św. Pawła, dominikanów (Arap Camii) w dzielnicy Galata, ufundowany przez rodzinę genueńskich łacinników. Dominikanie objęli kościół w roku 1325 i utrzymywali jako parafię służącą łacińskiej ludności zamieszkującej ten region aż do 1453 r., który Mahmet II (1451-1481) przemienił na meczet. Obok kościoła jest widoczna baszta genueńczyków otoczona obronnym murem ${ }^{18}$.

(H) Tuż obok w dzielnicy Galata był usytuowany kościół św. Jerzego, jeszcze $\mathrm{w}$ roku 1303 wymieniony jako trójnawowa bazylika z kopułą, w drugim przęśle środkowym poniżej w części chórowej znajduje się studnia, która była tutaj już w czasach cesarzowej Ireny, potwierdzona w dokumentach w roku 800. Po zdobyciu Konstantynopola były tutaj parafie prowadzone przez jezuitów, dominikanów i kapucynów. Dzisiaj kościół należy do austriackiej fundacji szpitalnej św. Jerzego.

\section{b) Budowle pałacowe}

(O) Stary pałac (topkai serai). Schedel przesuną jego usytuowanie wraz $\mathrm{z}$ bramą dworską $\mathrm{w}$ kierunku zachodnim, widziany jest fragmentarycznie niemal równolegle z kościołem św. Ireny. A. Bereger i J. Bardill powątpiewają w autentyczność tego miejsca i podkreślają brak realiów ${ }^{19}$. Brak jest ogrodu pałacowego, który ma wspaniałą historię ${ }^{20}$.

(J) Zamek Burg siedmiu wież (Yedikule Heptapyrgion) znajduje się po lewej stronie przestrzeni miasta z zaznaczonymi złoceniem herbami. Wkomponowana jest Złota Brama obejmująca odcinek murów miasta pamiętający

${ }^{16}$ Septuaginta czyli Biblia Starego Testamentu wraz z księgami deuterokanonicznymi i apokryfami, tłum. ks. R. Popowski, Warszawa 2013, 1313.

${ }^{17}$ A. Berger i J. Bardill (The Representations of Constantinople, s. 5) powattpiewają w autentyczność tego miejsca.

${ }^{18}$ Por. tamże, s. 21.

${ }^{19}$ Por. tamże, s. 15.

${ }^{20}$ Por. C. Dagron, Constantinople imaginaire: études sur le recceil des „Patria”, Paris 1984, passim. 
czasy cesarza Teodozjusza. Założenie zamkowe rozbudował cesarz Jan VI Kantekuzenos (1341-1355), natomiast Sułtan Mehmet II 1457/1458 przebudował zamek, nadając budowli funkcję twierdzy z charakterystycznymi siedmioma wieżami. Od roku 1895 znajduje się tam muzeum.

(K) Pałac Justyniana w dzielnicy miasta, nazwanej Blacherne. Ukazany jest jako najbardziej monumentalny i okazały, pamietający największe triumfy miasta. Schedel szczególnie uwypuklił to miejsce jako kompleks budowli pałacowych, który między IX a XIV w. został nazwany Tekfur Saray. Zachowane są trzy piętrowe fasady z ciemnej cegły i jasnym kamieniem, co odpowiada budownictwu wczesnego romanizmu, więc z tego czasu zachowały się wczesne polichromie. Pałac został odbudowany w XIX w., a w roku 1964 odrestaurowany.

(L) Warownia zaznaczona przez H. Schedla na wschód od pałacu Justyniana. Obronny zamek otoczony silnymi murami z wieżami stanowi kompleks obronny wybudowany przez cesarza Manuela I Komnenosa (1143-1180), znany jako pałac Hypsela. Wzmocniony został przez cesarza Isaaka II Angelosa (1185-1195) dodatkowymi murami i wieżami. W czasie zdobywania miasta w roku 1453 został zniszczony, ale fragmenty murów pozostały do dzisiaj.

\section{c) Kolumny}

(M) Kolumna Konstantyna została postawiona jako manifest godności cesarza w roku 328, w środku forum. W opisach Konstantynopola w czasach łacinników szczególnie czczona była pamięć cesarza. Unosiła złotą statuę cesarza Konstantyna Wielkiego. Schedel pokazuje kolumnę porfirową z postacią cesarza Konstantyna. Wysokość kolumny wynosiła $36 \mathrm{~m}$, bęben z porfiru miał 3,10 m i pochodził z Rzymu. W czasach $\mathrm{H}$. Schedla nie było już statui Konstantyna, a kiedy zniknęła statua cesarza - tego nie wiadomo. H. Schedel korzystał ze starszych opisów podróżników do Konstantynopola, które w formie literackich ekfraz opisywały wielkość cesarza Konstantyna Wielkiego. W czasach współczesnych H. Schedlowi nie było kolumny ani statui. Źródłem dla Schedla był opis silnego sztormu przekazanego przez weneckiego marszanda. Zniszczenia objęły ponad 800 domów oraz monumentów, m.in. kolumnę Justyniana, która stała na Augustaionie na południe od Hagia Sophia ${ }^{21}$.

(N) Kolumna z wężem (Burma sutun) należała do wielkich dzieł, które stały na hipodromie circus maximus, a pochodziła z Defphi, uczyniona przez greckich mistrzów jako manifest przeciwko Persom. Konstantyn Wielki przywiózł kolumnę do Konstantynopola. Na planach i rysunkach miasta z XVI w. była widoczna jeszcze z wężem miedzianym na szczycie. Po roku 1700 wąż został zdjęty (albo zniszczony), a część głowy została zachowana w Muzeum Archeologicznym w Stambule.

\section{d) Mury obronne i bramy}

(R) Podwójny pierścień murów obronnych jest eksponowany jako pierwszy ciag murów od strony zachodniej miasta, który jest dzisiaj tylko hipote-

\footnotetext{
${ }^{21}$ Por. Berger - Bardill, The Representations of Constantinople, s. 15.
} 
tyczny. Obraz H. Schedla pokazuje zamknięty obwód murów lądowych, które biegną od Złotej Bramy i obejmują zamek z siedmioma wieżami w części zachodniej do fragmentu Blacherny, łącząc się z murami Tekfur Saray do Złotego Rogu. Budowę murów łączy się z cesarzem Teodozjuszem II, w roku 432 zostały fragmentarycznie zakończone prace. W następnych latach mury były podnoszone, szczególnie wieże. Intensywne prace nastąpiły po zdobyciu Konstantynopola w XV w., a w roku 1453 rozumiano je jako zasadnicza obronę miasta. Dzisiejsze ruiny są monumentem pamiątkowym z całej historii Bizancjum, gdzie długość fragmentu od małego portu z galerami i okrętami w pobliżu Złotej Bramy do Blacherny obejmuje łuk $6,5 \mathrm{~km}$. Mury były wysokie na $11 \mathrm{~m}$, szerokie na 4, $80 \mathrm{~m}$. Liczba wież zaznaczonych na planie i ich kształt pozostaje rzeczą umowną oraz nie odpowiada realiom. Mury od strony morza są wysokie na $11 \mathrm{~m}$. Schedel wyeksponował ich wysokość w części morskiej w całym obwodzie, ale zostały podzielone na odcinki z podwójnymi bramami. W tym miejscu upatruje się bardziej idee murów i bram aniżeli realne odwzorowania.

(S) Pera, genueńska Galata zamknięta murem obronnym z Bramą Galata. Podwójne szeregi murów obronnych otaczają miasto w kształcie zaokraglonym, otwarte tylko od południowego zachodu, w kształcie rogu przestrzeń między murami jest szeroka i pusta, widać już domy lokowane z tyłu za murami. Konstantynopol był prawie pusty w okresie po 1453 r., co potwierdzaja badania historyczne. Liczne budowle, zwłaszcza kościoły, które artysta odzwierciedlił, nawiązują do widoku miasta sprzed $1453 \mathrm{r}$.

(Q) Złota Brama została wyeksponowana przez H. Schedla z lewej strony widoku miasta. Dekoracje herbów odpowiadają złotej koronie z czasów, kiedy miasto zostało określone jako złota korona. Mury i bramy nawiązują tu do rzymskiej architektury z czasów Aureliana, co zostało spowinowacone z reprezentacyjnym łukiem triumfalnym. Nowy rodzaj manifestowania władzy i zwycięstw został w czasach cesarskich Konstantynopola utożsamiony nie $\mathrm{z}$ łukiem triumfalnym, ale $\mathrm{z}$ bramą. Miasto posiadało trzy przejścia potrójne, przejście do wnętrza miasta - od strony miasta i od strony otwartej przestrzeni. Wypisane były znaczące inskrypcje wyryte złotymi literami, od strony otwartej inskrypcja głosiła ,,aurea saecula gerit qui portam construit auro (Do złotego wieku prowadzi ten który zbudował Złotą Bramę)"22. Dzisiejszy widok przedbramia pochodzi z XIV w.

3. Urbs - civitas $\mathbf{w}$ tradycji obrazowania miast w średniowieczu. Widok miasta Konstantynopola ukazany przez H. Schedla (podobnie jak wszystkie inne panoramy w jego Kronice) jest wizją miasta urbs. Definicję znaną w średniowieczu przekazał, według tradycji antycznej, Izydor z Sewilli, który odróżnił definicję civitas od urbs: „Civitas est hominum multitudo societatis vinculo adunata, dicta a civibus, id est ab ipsis incolis urbis, nam urbs

${ }^{22}$ W. Holtz, Byzanz, Konstantinopel, Istambul. Handbuch der Kunstdenkmäler, Berlin 1971, 97. 
ipsa moenia sunt, civitatis autem non saxa, sed abitatores vocantur" ${ }^{23}$. Urbs jest zbiorem architektury domów, kościołów, murów, architektury sakralnej i cywilnej, obronnej, rezydencjonalnej, gdzie z istoty budowle odnoszą się do gospodarzy, właścicieli i użytkowników, jednak są oni niejako ukryci w definicji. Podmiotowy charakter ma pojęcie civitas ze zbiorem ludzkim, uporządkowanym zasadami prawnymi. Miasto Schedla jest gęsto zabudowane, ale jest puste, jedynie enigmatyczne figurki zaznaczone są na galerze skierowanej do bramy zwanej morską. Miasto jest zbiorem historii budowli, które odnoszą się do dziejów historycznych, nawet bardziej odległych aniżeli samo jego założenie. Sprowadzone monumenty: obelisk z Karnaku, kolumny, posagi, detale architektoniczne tworzyły historię miasta. Miasto miało aspiracje środowiska nowoczesnego, a nawet nowatorskiego w budowlach Justyniana. H. Schedel oddał tradycje greckie, wschodnie i łacińskie chrześcijańskie kościół dominikanów św. Pawła w Galata z roku 1325, cesarska rezydencja, fortyfikacja zamek ,siedmiu wież” z 1350 r. Precyzyjnie wykreślony okrąg obszaru miasta, zamkniętego podwójnym ciagiem murów obronnych, które w czasie tworzenia planu już nie istniały, w zamkniętym obwodzie z kilkudziesięcioma basztami wieżami i bramami. Istniejące do czasów najnowszych studia nad historią miasta i odniesienie wiedzy archeologicznej i historycznej do zachowanych planów Konstantynopola wykazały różnice w oddaniu różnorakich akcentów realnych form architektonicznych sakralnych i świeckich, które nie są realnym odbiciem widoku miasta z końca XV w. Konstantynopol prezentuje widok idealny, gdyż miasto jest zbiorem budowli jako znaków upamiętniających konkretne zdarzenia przekazane w opisach. Niektóre budowle są wprowadzone z czasu przed wielkim huraganem, nawałnicą, która przeszła nad miastem w dniu 12 czerwca 1490 r., w wyniku której zniszczonych zostało 800 budynków i monumentów.

Kompozycja miasta H. Schedla stanowi panoramę ukształtowaną w eliptycznym łańcuchu rozciągniętym nad wodą o niezrozumiałym kierunku łodzi, co - jak dostrzega się w badaniach - zakłóca klarowność układu i zaciera realia. Konstantynopol, mimo rozpoznawalnych niektórych budowli, stanowi jako całość raczej twór wyobraźni, w którym uwzględniono różne źródła i niektóre realia historyczne. Kronika $\mathrm{H}$. Schedla jest kroniką, a nie kopią jakiegokolwiek gotowego widoku. Brak jest zupełnie zainteresowania życiem człowieka, brak jest przyrody, z wyjątkiem żywiołu wody, nie ma imponujących w Konstantynopolu ogrodów, nie tylko pałacowych. Ciężkie mury otaczają miasto w kształcie zaokrąglonym, a są otwarte tylko od południowego zachodu w kształcie rogu - przestrzeń między murami jest szeroka i pusta, widać domy lokowane za murami, jeden brzeg Marmara i Złoty Róg ${ }^{24}$. Konstantyno-

${ }^{23}$ Isidorus Hispalensis, Etymologiae XV 2, 1. PL 82, 536.

${ }^{24}$ Być może chodzi o podkreślenie portu Złotego Rogu, pierwszy raz wymienionego w latach 717-718; za Berger - Bardill, The Representations of Constantinople, s. 5. 
pol był prawie pusty w okresie przed 1453 r., co potwierdzają źródła ${ }^{25}$. Wskazuje się na bezpośrednie źródło inspiracji, czyli panoramę Cristofora Buondelmontiego wykonaną w roku $1422^{26}$. Różne są wersje widzenia panoram z lotu ptaka: miasto H. Schedla zostało ukazane z poziomu płytszego kąta pochylenia aniżeli widok Buondelmontiego. Bez wątpienia dla obu autorów istotny był pierścień podwójnych murów obronnych z licznymi bramami zarówno od strony wybrzeża morza Marmara, jak i lądu. Małe wieże, jak latarnie, są obok Hagia Sophia na planie Buondelmintiego, ale nie ma ich u H. Schedla. Widok kolumn Justyniana i pałacu Blacherne jest odmienny. Buondelmonti widział kilka kolumn, a H. Schedel tylko jedną, Justyniana, którą z determinacją odrysował w swoim widoku. Pozostałe mają szerokie, cebulaste zwieńczenia, dwie w obrębie pałacu imperialnego i cztery w obszarze zabudowań północno-zachodniej części miasta. Dopiero H. Schedel znał stan miasta po wielkim huraganie, którego nie znał twórca panoramy z roku 1422.

\section{4. Średniowieczna tradycja religijna urbs przekazana w tekstach i ob-}

razach. W średniowiecznej tradycji wizualizacji miast znane były liczne wyobrażenia miast według modelu urbs. Podstawą były opisy miast biblijnych, a nade wszystko toposem nadrzędnym było miasto Boga - Niebieskie Jeruzalem - przekazane w opisie Apokalipsy (21, 10-21). Obraz niebiańskiego Jeruzalem wyznaczał mur z drogocennych kamieni. Takie wizje przekazały mozaiki rzymskie oraz widoki miast ukazane w miniatorstwie średniowiecznych kodeksów. Najwcześniejszy, szczególnie wyrafinowany sposób ukazywania obrazu miasta wykształcił się w skryptorium benedyktyńskim klasztoru w Reichenau na przełomie X i XI w. Wyobrażenia miasta znane z tradycji późnoantycznej i wczesnochrześcijańskiej miniatorstwa syro-palestyńskiego utrwaliły zamknięte murem obronnym okragłe terytoria jako swoiste „plastry” rzucone na gładkie tło. Przykładem mogą być wizje miast Syrii, Jordanii. Widok monumentów rzymskich na mozaice Santa Pudencjana odnosi się do wizji miasta świętego Jeruzalem ${ }^{27}$. W miniatorstwie romańskim są zaznaczone umowne, gęsto zestawione, identyczne budowle stanowiące ,ciało wspólnotowe", ponad którym dominuja jedynie wybrane charakterystyczne dla miasta świątynie lub siedziby władców. Jest to rozumienie uniwersum jako ciała wspólnotowego universum cristianum ponad którym w roli indywiduum są ukazane budowle kościelne stanowiące abrewiacje caput, głowy w rozumieniu eklezjalnym.

${ }^{25}$ Por. A.M. Schneider, Die Bevölkerung Konstantinopels im XV. Jahrhundert, Nachrichten der Akademie der Wissenschaften in Göttingen, Philologisch-Historische Klasse Nr. 9, Göttingen 1949, 233-244; za: Berger - Bardill, The Representations of Constantinople, s. 3, nota 5.

${ }^{26}$ Por. Berger - Bardill, The Representations of Constantinople, $\mathrm{s} .7 \mathrm{nn}$. W nocie 13 są opisane nowsze badania.

${ }^{27}$ Por. C.D. Fonseca, La citta immaginata: dalla rappresentazione del mondo alla Gerusalemme celeste, w: Imago urbis, s. 7-15. 
W XIV-wiecznym malarstwie włoskim, zwłaszcza ze Sieny, zarówno na freskach, jak i na tablicach, został utrwalony model miasta bardzo zabudowanego z nagromadzonymi budowlami, które odróżnia barwa, czasem archaiczna, antykizujacca forma. W tym sensie mistrzami miast $\mathrm{w}$ swoim malarstwie byli Duccio di Buoninsegna (1255-1318) i Giotto di Bondone (1266-1337) ${ }^{28}$. Celem takiej wizji było unaocznienie siły i potęgi miasta, także jako spójność czasów minionych Starego Testamentu z czasami Ewangelii. W tych gęsto zabudowanych skupiskach, zamkniętych murami istotne znaczenie miały budowle wybrane, a konkretnie rozpoznawalne jako szczególnie ważne miejsca ukazane ze względu na temat wyobrażenia i narrację pierwszego planu. Przykłady i zarazem wzorce dla całego średniowiecza pozostawiły wyobrażenia włoskie $^{29}$. Spadkobiercą rzymskich tradycji były mozaiki w San Apolinare Nuovo w Rawennie, które ukazują symetrycznie znaczenia: palatium civitas w nawie głównej bazyliki ${ }^{30}$. W średniowiecznym malarstwie włoskim, zwłaszcza w tablicowym i freskowym, wyróżniają się widoki imponujących makiet, modeli miast pozbawionych codziennego życia, które stanowią środowisko dla narracji pierwszego planu, jak to ukazał w wystudiowanych widokach czterech miast - państw Cimabue, Cenni di Pepi (1240-1302) na freskach w sklepieniu transeptu bazyliki górnej św. Franciszka w Asyżu z lat 1270-1280 ${ }^{31}$.

Szczególnie licznie w tradycji włoskiej zostały utrwalone modele miast - urbs ukazane jako wotum ofiarowane świętym patronom, zwłaszcza Maryi. Miasto w takich obrazach było stałym modelem owalnego, elipsoidalnego pierścienia zamkniętego murem obronnym. Stanowiło w ten sposób swoisty „pojemnik" wypełniony budowlami z wyróżnionymi dla konkretnych miast monumentami sakralnymi. Były one konkretyzowane dzięki inskrypcjom oraz charakterystycznym dla miasta inwokacjom umieszczanym poniżej lub ponad sceną. Obraz i tekst stanowiły niejako dwie nierozdzielne sekwencje przejęte $\mathrm{z}$ tradycji miniatorskiej. Cytujemy w tym miejscu najbardziej charakterystyczne przykłady badane przez Chiarę Frugoni ${ }^{32}$. Taddeo di Bartolo (1362-1422) na fresku w Palazzo Pubblico w Sienie namalował sieneńskiego dominikanina Ambrogia Sansedoniego, który trzyma model swojego miasta z najbardziej rozpoznawalną budowlą - katedrą NMP. Ten sam malarz, określany w badaniach jako mistrz widoków miast wotywnych, namalował św. Antillę z modelem Montepulciano na obrazie z roku 1401 dla katedry Wniebowzięcia NMP w Montepulciano ${ }^{33}$. Biskup miasta Gimignano, św. Gimignanus na obrazie

${ }^{28}$ Por. D. Popp, Duccio und die Antike. Studium zur Antikenvorstellung und zur Antikenrezeption in der Sieneser Malerei am Anfang des 14. Jahrhunderts, München 1996.

${ }^{29}$ Por. Frugoni, A Distant City, s. 5-24.

${ }^{30}$ Por. tamże, s. 39nn.

${ }^{31}$ Por. taż, L'Ytalia di Cimabue nella basilica superiore di Assisi. Uno squardo dal transetto alla navata, w: Imago urbis, s. 33-63.

${ }^{32}$ Por. taż, A Distant City, passim.

${ }^{33}$ Por. U. Mazurczak, Geneza i rozumienie votum w kulturze europejskiej $i$ w tradycji chrześcijańskiej. Miasto jako votum dla Maryi i świętych, na wybranych przykładach malarstwa włoskiego, 
wykonanym przez tego samego mistrza T. di Bartolo w roku 1393 (San Gimignano, Museo Civico) prezentuje miasto w kształcie soczewkowego pierścienia zamkniętego murem obronnym z licznymi wieżami kościelnymi oraz siedzibami feudalnymi, charakterystycznymi dla miasta. Jego makieta jest modelowana piramidalnie, wzgórza wznoszą się na stromych zboczach ku górze, odzwierciedlając zbliżoną analogię - topografię miasta. W takim jednak zgeometryzowanym kształcie została oddana figura miasta, w sensie biblijnego „miasta na górze”. Model miasta bardzo mocno trzyma święty, aby przez przyleganie do jego ciała odzianego w szaty ceremonialne oddać sens korporalny urbs pod opieką biskupa, patrona modlącego się za miasto. Analogicznie ukazał model miasta malarz sieneński Meo da Siena. Biskup Erolamo, patron Perugii trzyma model miasta niemal na swoim ciele. Widok ograniczony został do fragmentu Piazza Maggiore z katedrą (Perugia Galleria Nazionale dell' Umbria) $)^{34}$. Do serii wyobrażeń miast jako makiet unoszonych przez świętych patronów należy makieta miasta Empoli, ukazana za św. Mikołajem z Tolentino. Obraz został namalowany w roku 1450 przez Bicci di Lorenzo (Empoli katedra Santo Stefano). Bernardo Daddi ukazał Madonnę Misericordia z widokiem Florencji ${ }^{35}$. Tommaso da Modena ukazał św. Katarzynę z modelem miasta Treviso na fresku z kościoła św. Katarzyny w Treviso ${ }^{36}$. Przełomem jest widok miasta Sieny z jego contado, Ambroggia Lorenzetiego w Palazzo Pubblico w Sienie. Wyobrażenie to jest pochwałą dobrych rządów miasta Sieny i przestroga przed rządami złymi, więc ma zupełnie inny charakter i pełni inną funkcję. Modele miast - makiet zamkniętych murem obronnym z eksponowanymi realnymi budowlami są wkomponowane w gęsto zabudowane struktury, rozpoznane dzięki tekstom wotywnym wypisanym na tablicy lub zwoju trzymanym w dłoni świętego $\mathrm{z}$ tekstem sentencji.

Nawiązują do tradycji piśmiennictwa znanych form laudes, pisanych ku czci miast ze względu na historię. Widoki miast wotywnych były również pochwałą, dziękczynieniem skierowanym ku Bogu i w takim kontekście należałoby rozpatrywać sens wotywnych makiet jako malowanych hymnów dziękczynienia, jakie znała tradycja antyczna. Spośród wielu tekstów możemy w tym miejscu zacytować jedynie niektóre, istotne wzorce dla średniowiecza. Liczne teksty powstałe jako pochwały dla miast - laudes civitatum nie określały realnych detali życia, ale wielkość, potęgę, świętość miasta jako zbiór monumentów. W pieśni poetyckiej laudes civitatum Gina Fasoli wyrażane były głębokie westchnienia, przeżycia religijne podobne pieśniom pochwalnym ku pamięci Mediolanu, Werony, Bergamo, Pawii. Stanowią hymniczną

w: Zespót zabytkowy Piotrawina - promocja dziedzictwa. Materiały konferencji naukowej w Piotrawinie 2014, red. R. Bartnik, Lublin 2016, 77-98.

${ }^{34}$ Por. Frugoni, A Distant City, s. 78.

${ }^{35}$ Por. tamże, s. 80; L. Beccherucci - G. Brunetti, Il Museo del' Opera del Duomo a Firenze, Milano 1970, 118-119; Mazurczak, Geneza i rozumienie votum w kulturze europejskiej, s. 86.

${ }^{36}$ Por. L. Menegazzi, Tomaso da Modena, Treviso 1979, 165, il. 15. 
pochwałę zwycięstw, triumfów, ale również klęsk i cierpień. W środowisku włoskim były rozpowszechnione laudy Bonvesin de la Riva De magnalibus Mediolani (1288), anonimowego autora (Opinio de Canistris?) znanych Liber de laudibus civitatis ticinensis datowanych na ok. 1330 r. Nawiązał on do Bonvesin de la Riva i wzoru jego miasta, jest to pochwała władców, zwłaszcza Pawii $^{37}$. Giovanni Villani opisując Florencję wymienia najpiękniejsze budowle świeckie i religijne, architektów i artystów. Miasto w kronice Villaniego jest przede wszystkim pięknym miastem ${ }^{38}$.

Pochwały miast włoskich powstałe we wczesnym średniowieczu w kręgu klasztorów benedyktyńskich często nawiązują do tekstów ku czci miast biblijnych. Autorzy tych tekstów wplatali pamięć rodzinnych miast jako miejsc czci, szczególnie Maryi. Forma literacka wyrażała jednoznacznie, że bohaterem jest miasto, a nie jego mieszkańcy, stąd słusznie jest używane słowo urbs, a nie $c i$ $v e{ }^{39}$. Szczególnie sentymentalno-elegijny charakter miały laudy ku czci miast zniszczonych, często nawiązywały do miast Starego Testamentu, np. Niniwy. Pamięcią - wzorem Miasta była również zniszczona Jerozolima. Opis upadku Jerozolimy, przekazany przez Fulcheria z Chartres w Historia Hierosolimitana, był kroniką zniszczenia i cierpienia, spisaną w trzech księgach. Opowiada o upadku miasta pomiędzy 1095 a 1112 rokiem $^{40}$. Znajdują się tu opisy zniszczenia $\mathrm{w}$ rozumieniu materialnego dorobku historycznego miasta, które porównano do cierpiącego ciała. Zniszczenie murów było symbolem upadku ducha miasta. W wizji Fulcheria znajdują się metafory miasta Jerozolimy jako centrum wszechświata - kosmiczne centrum i środek ziemi porównywany jest ze środkiem anatomii człowieka. Kanonik z Chartres był kapłanem i kustoszem kościoła NMP w Chartres - mieście rodzinnym. Tutaj urodził się w roku 1058 i stąd wyruszył na Wschód razem z księciem Normandii Robertem. Wjechali do Edessy, Jerozolimy. Jego opis pielgrzymki zachował nawiązania do opisu Ezechiela (por. Ez 8, 3-12). Miasto bez murów stało się symbolem ludu Izraela, opuszczone przez Boga. W późniejszych panegirykach ku czci Jerozolimy, np. w dziele Jacquesa de Vitry Historia Ierosolymitana seu orientalis, napisanym podczas jego pobytu w Akrze pomiędzy 1218 a 1229 r., gdzie pełnił godność biskupa tego miasta, znaczenie Jerozolimy wyniesione zostało do roli centrum spełnionej historii Starego oraz Nowego Testamentu ${ }^{41}$.

5. Miasto - Arkadia w nowożytnej szacie. H. Schedel jako bibliofil i uczony humanista znał teksty średniowiecznych pisarzy, gdyż jego aspiracje

\footnotetext{
${ }^{37}$ Por. Frugoni, A Distant City, s. 79nn.

${ }^{38}$ Por. Giovanni Villani, Cronica VIII 3, 1710, ed. G. Aquilecchia, w: Cronica [di] Giovanni $i$ Villani, con le continuazioni de Matteo e Filippo, scelta, introduzione e note di G. Aquilecchia, Nuova Universale Einaudi 159, Torino 1979, 216.

${ }^{39}$ Por. Fonseca, La citta immaginata, s. 70.

${ }^{40}$ Por. tamże, s. 71.

${ }^{41}$ Por. tamże.
} 
jako humanisty nie mogły pomijać współczesnych tekstów, pisanych na bazie starożytnej literatury rzymskiej obficie kopiowanej dla nowych odbiorców. Nowe prądy renesansu włoskiego docierały do południowych Niemiec i Norymbergi poprzez Lombardię oraz Wenecję w XIV i XV w., zanim zdominował je neoplatonizm z Florencji. Uczony znał również przekazy podróżników i pielgrzymów do Ziemi Świętej, ponieważ były one źródłem wiedzy o regionie już zamkniętym, niebezpiecznym i dostępnym jedynie śmiałym podróżnikom. Poszukujący wiedzy o świecie gromadzili wszelkie, również mniej uprawomocnione przekazy, na poły legendarne i fantastyczne. W czasach życia H. Schedla w środowisku Norymbergi pierwszoplanowe znaczenie miały kontakty handlowe i gospodarcze zapewniające bogatemu miastu produkty luksusowe, które docierały różnymi drogami, również poprzez Konstantynopol. Metropolia w politycznym statusie nie należała już do chrześcijańskiej wschodniej oikumene. Była miastem pustym i ubogim, jak je określają badacze historii, splądrowanym, spalonym i zniszczonym. Upadek Konstantynopola i zajęcie przez islam świątyń oraz pałaców spowodowało upadek jego prestiżu w życiu religijnym oraz politycznym Europy. Miasto, co prawda osłabione, zachowało kontakty ekonomiczne z Europą łacińską, która u progu swojego nowożytnego rozwoju gospodarczego potrzebowała minerałów i surowców dla produkcji towarów luksusowych. Z kolei Konstantynopol również potrzebował towarów, które zapewniały mu niezbędne codzienne funkcjonowanie, mianowicie soli dostarczanej dzięki dawnym kontaktom z Genuą i Wenecją. Towary żywnościowe, korzenne, przemysłowe, a zwłaszcza tkaniny oraz cenne barwniki zapewniały wzajemne korzyści handlu pomiędzy łacinnikami i odbiorcami mieszkającymi w obrębie Wschodu, pomiędzy którymi Konstantynopol był łącznikiem. Podtrzymywana była wzajemna wymiana towarów, a tym samym i finansów.

W krajach południowoniemieckich szczególnie ceniono handel bawełna, z której tkano barchany, tkaniny cenione w tym kręgu klimatycznym. Zapotrzebowanie wzrosło jeszcze bardziej w obszarze górskim południowoniemieckim i w Lombardii, kiedy pod koniec XV w. nastapiło ochłodzenie klimatu, a upalne okresy lata znacznie skróciły się ustępując chłodniejszym i deszczowym. Rozwijający się przemysł tekstylny w południowych obszarach Niemiec i Lombardii wzmacniał status rzemieślniczy również samej Norymbergi czy Mediolanu. Miasta te poprzez wysłanników wielkich kampanii weneckich utrzymywały zamówienia dla wielkiego weneckiego transportu, wielu towarów żywnościowych i przemysłowych. Gospodarcze kontakty miast europejskich z Konstantynopolem podtrzymywała pamięć wspólnoty chrześcijańskiej, która w ograniczonym stopniu została zachowana poprzez działalność bractw i klasztorów, m.in. dominikanów, potem jezuitów. Obszerne badania historyczne wykazuja, że pomimo sporów religijnych między światem łacińskim a bizantyńskim, więzy gospodarcze i religijne zacieśnione przed rokiem 
1453 trwały do schyłku XV wieku ${ }^{42}$. Szczególnie ważne w podtrzymywaniu świadomości religijnej były relikwie gromadzone w Rzymie, święte obrazy kultowe w całej Europie, stanowiące niezmienny wzór ikony Konstantynopola.

Potrzeba luksusu w łacińskich monarchiach skłaniała do szukania nowych kontaktów z Konstantynopolem, który był centrum zainteresowania Egiptu i handlu z portem w Aleksandrii, szczególnie ważnym w przewożeniu towarów i cennych surowców, np. kości słoniowej ${ }^{43}$. Znaczenie Konstantynopola pozostało głęboko w świadomości łacinników od okresu krucjat, które wytyczyły drogi lądowe do Ziemi Świętej przez Bałkany, dalej przekraczany był Bosfor w Konstantynopolu, w celu przejścia przez Wyżynę Anatolijską ${ }^{44}$. Konstantynopol był punktem zbornym w którym spotykały się lądowe krucjaty z terenów Europy Północnej: Anglii, Flandrii, Normandii. Mimo nieufności, jakie budziły wielkie rzesze łacinników w Konstantynopolu, miasto bogaciło się na organizacji i zapewnieniu noclegów i żywności, co było dla pielgrzymów dość kosztowne ${ }^{45}$. Trasy te jako znane i sprawdzone przejścia komunikacji handlowej były aktualne w XIV i w XV w.

Rolę pośredników w utrwalaniu dorobku kulturowego i religijnego Konstantynopola w świadomości europejskiej odegrały miasta Wenecja i Genua. Miasta te zdominowały cesarstwo bizantyńskie zwłaszcza po roku 1204, pozostawiając spore pole dla późniejszych związków osobowych i szerszych kontaktów. Interpretacje historyków dotyczące 57-letniej dominacji łacińskiej w Konstantynopolu pozostawiły obszerne studia, które określiły w różnym stopniu rzeczywistość gospodarczą i polityczną. Wenecja, mająca pozwolenie na rozszerzenie obszaru urbanistycznego, zadbała o jego zagospodarowanie również intelektualne, co miało korzystny wpływ na całe miasto. Powstawały ośrodki tłumaczeń dzieł Arystotelesa, Hipokratesa, Archimedesa i Ptolemeusza dające Europie późnośredniowiecznej kopie źródłowych dzieł. Znacząca była w tym zakresie praca translatorska arcybiskupa Koryntu Wilhelma Moerbeke. W cesarstwie łacińskim były wydawane dzieła historyczne Godfryda Villehardouin, Roberta Clari, Henryka Valenciennes. Rozwinięto warsztaty złotnictwa, które pozostawały pierwotnie wyłącznie pod władzą bizantyńskich dworów cesarskich, a z czasem stały się warsztatami miejskimi zwielokratniającymi eksport na dwory królewskie Europy. Poszukiwane i cenione wyroby z kości słoniowej, złotnicze, emalie, kosztowne tkaniny jedwabne, wyroby z cyny znajdywały licznych odbiorców monarszych. Pracownie iluminacji kodeksów botanicznych i ksiag świeckich były cenione w rozwijającej się pod względem kultury intelektualnej Europie. W Konstantynopolu powstawały ośrodki łacińskie w kościele Kalenderhane Cami, gdzie jest zachowany cykl z życiem św. Franciszka. Konstantynopol stanowił bogaty re-

\footnotetext{
${ }^{42}$ Por. M. Balard, Łaciński wschód XI-XV wiek, thum. W. Ceran, Kraków 2010.

${ }^{43}$ Por. tamże, s. 33.

${ }^{44}$ Por. tamże, s. 54.

${ }^{45}$ Por. tamże, s. 59.
} 
zerwuar cennych pamiątek materialnych i ogromny potencjał intelektualny. Dokonywała się tutaj po połowie XV w. asymilacja materii z ideami, które nadawały jej nowe znaczenie. Rzeczy otrzymywały „dusze”, aby mogły trwać $\mathrm{w}$ tym ponadmaterialnym wymiarze pamięci. Monumenty, budowle pozostałe w Konstantynopolu tworzyły obraz idealny miejsca idylli - przybierającej cechy elegii, czasem wzniosłego agonu. Jedno więc i drugie nadawało siłę oddziaływania na stary kontynent chrześcijański w intensywnym okresie neoplatonizmu renesansowego. Grecka tradycja języka i literatury, przyniesiona z Konstantynopola najpierw do Italii, a potem do Europy zaalpejskiej, ożywiła wczesnorenesansowe nurty i utrwalający się religijny synkretyzm, który łączył mitologię z heroiką świętych.

Pasterska idylla, można powiedzieć, wyszła z Wenecji, gdzie zostało wydane drukiem w 1470 r. ilustrowane wydanie dzieła Wergiliusza. Później w 1497 r. w oficynie Aldusa Mancjusza zostały wydane dzieła Owidiusza: Fasti i Metamorfozy, w 1499 r. Francesca Colonny Hypnerotomachia Poliphilii, a w 1502 r. Arcadia Jacobo Sannazaro, która powstała w roku 1480, rozpowszechniając się w manuskryptach ${ }^{46}$. Stworzony został klimat literacki, który monumenty historii ukazywał w nowych poetyckich topikach pamięci i nowej metamorfozy ${ }^{47}$. Ten styl pochodził z dworskiej tradycji bizantyńskiego Konstantynopola i był osadzony na literaturze greckiej. Zdołał się już wytworzyć model znany - idylli połączonej z miastem, ale w rozumieniu urbs jako zbioru historii, a nie realnego życia mieszczańskiego, adekwatnego do pojęcia civitas. Powstał twór pośredni locus amoenus - dolina Tempe z dzikim lasem, skałami, strumykiem szemrzącym ciche murmurando roztaczała się w pobliżu miasta. Idealny krajobraz złożony był z realiów: drzew, dębu, platanu, akacji, wawrzynu, były konkretne kwiaty, łąki pastwiska oraz źródła i rzeki. W łacińskiej literaturze zadomowiły się motywy architektury świątyń, portyków, teatrów, wnoszące wspomnienia utraconych siedzib. Tę ideę miasta pamięci, tęsknoty, niemal raju utraconego, rozwinął Wergiliusz w toposie swojego rodzinnego miasta Mantui ${ }^{48}$.

Spirytualizacja motywu arkadii została dokonana w greckiej literaturze patrystycznej. Teksty religijne, wzbogacane metaforyką niegdysiejszych pieśni pasterskich, zabarwione dźwiękami syryngi lub fletu rozwinęły literackie ekfrazy miejsc idealnych - świętych, co w istocie było dogmatyczną sprzecznością, ale docierało do wyobraźni ówczesnych elit dworskich. Połączenie Niebieskiego Jeruzalem - Civitas Dei oraz Raju z arkadią weszło na stałe do programów malarskich czego, np. dojrzałym przykładem są freski w kościele św. Piotra w Civate z roku 1180. Plastyczna wizualizacja, zwłaszcza mozaikowa oswajała literackie toposy: rzeki, rybaka, z pasterzem i owcami, a wszyst-

${ }^{46}$ Por. P. Schafer-Maisak, Arkadien Genese und Typologie einer idyllischen Wunschwelt, Frankfurt am Main - Bern 1981.

${ }^{47}$ Por. tamże, s. 59.

${ }^{48}$ Por. tamże, s. 25. 
ko to na tle miasta świętego Jeruzalem. Malarska wizualizacja zmysłowo oddziaływująca barwami i formami utrwalała nowe kontaminacje pasterza niegdysiejszej doliny Tempe i miasta na horyzoncie. Aktualność tego wątku w malarstwie średniowiecznym dostrzegana jest już w XIV w.

Szczególnie intensywnie odżyły wizje świata idealnego, u schyłku średniowiecza i początku czasów nowożytnych, owładniętych wczesnym kapitalizmem, rządzą silnych struktur finansowych, handlowych gospodarczych, wczesnej industrii. Wtedy to połączono dawne przeciwieństwa pasterza z rycerzem, a arkadii z miastem. Odżywała tradycja literatury greckiej i łacińskiej pokazującej możliwość koherencji wyobraźni z realiami życia. Recepcja arkadii Wergiliusza dokonywana $\mathrm{w}$ średniowiecznej literaturze podejmowana była intensywnie w kręgach elit, które również zmieniały swój charakter, ale zawsze potrzebowały idealnych przestrzeni, natomiast historia łagodziła swoją konkretną temporalność, nawet jeżeli nie do uniknięcia były czasy niosące krew walkę i śmierć. Krajobraz staje się ubogacony szczytami skalnymi, a na drogach pojawiają się rycerze na tle miast.

Siła znaczenia kulturowego i historycznego w zachowanych loci jako greckiej starożytnej historii i pamięci chrześcijaństwa była istotą we wczesnorenesansowej kulturze europejskiej poszukującej korzeni chrześcijaństwa w antyku. Początki badań historycznych to poszukiwanie korzeni szczególnie greckich, więc stanowiły one dla humanistów również ożywienie literatury. Pomimo upadku siły ekonomicznej, Konstantynopol oferował własny rezerwuar doświadczeń renesansu rozwiniętego w dworskich środowiskach dynastii Komnenów i Paleologów. Uczeni filozofowie, poeci i thumacze kształtowali środowiska humanistyczne Wenecji, Florencji oraz humanistów Norymbergi. Ożywiony został typ loci, który znany jest z przekazu Wergiliusza z realiami krajobrazu i miasta. Woda, potęga morza, rzeki okalające miasto, to wszystko określa ekfrazę życia biologicznego i botanicznego jako synonimu trwania, które było dla Wergiliusza pamięcią monumentów architektury. Na nowo odczytana arkadia z loci amoenus zawierała w sobie historię także człowieka. Złoty Róg obfitości i satyr są obrazowym unaocznieniem obfitości ziemi i łask natury.

Arcadia schyłku XV w., przygotowana znacznie wcześniej przez Dantego i Pertarkę, została określona dla humanistów schyłku średniowiecza w prototypie Jacobo Sannazaro. W dantejskiej wizji arkadia zachowywała wyraźne kontury starożytnego pasterza i bukoliki pasterskiej, jednocześnie zaczepiona o Wergiliusza oddawała hołd cesarstwu rzymskiemu z jego siła polityczną - władzą cesarza. Restitudo antiquitatis dokonane przez Dantego, było już prostym wektorem dla Quattrocenta koncepcji antyku odradzającego się u początku nowożytności ${ }^{49}$. W XIV w. intensywnie kontynuowany był typ bukoliki w nowej wszak recepcji, odpowiadającej wykształconym odbiorcom już nie tylko według modeli scholastycznego wykształcenia. Dlatego bukoliki Dantego, Petrarki czytane były w środowisku bolońskich humanistów, środowisku

\footnotetext{
${ }^{49}$ Por. tamże, s. 373-390 - bibliografia.
} 
naukowym aspirującym do zgłębiania wiedzy z zakresu nauk ścisłych w dzisiejszym rozumieniu. Giovanni Virgilio, boloński humanista, stworzył pasterza jako figurę ,złotego wieku” utożsamionego z czasem antycznym, który odradzał się w czasach jemu współczesnych ${ }^{50}$. Pieśni typu carmen budowane na topikach ideałów: przyrody, miast, ludzi, bogów, rozumiane były w dworskich środowiskach monarszych i feudalnych Europy łacińskiej. Wykształcenie prawnicze z zakresu wiedzy o przyrodzie, o medycynie, a także potrzeba wiedzy o świecie, nakierowały poszukiwania źródeł antycznych zarówno śródziemnomorskich, jak i wschodnich. W bukolikach asymilowała się mitologia ze światem realnym. Natura i krajobraz emanujący pięknem, powabem życiodajnych źródeł rzek, powietrzem, określanym jako l'agitation de l'air był zarazem realnym środowiskiem ziemi urodzajnej, użytecznej i życiodajnej jako pastwisk dla bydła. Odradzająca się stale przyroda, w swoim pięknie drzew z ich konarami, napełnionych wewnętrznym źródłem, była obrazem życia wegetatywnego, zmysłowego, które jest źródłem idei. Te realne siły legły u podłoża neoplatonizmu rozwijanego w kręgu medycejskim Marcilia Ficina, Pico della Mirandoli, poezji Lorenza i Poliziana. Nawiązaniem bezpośrednim do Wergiliusza idei arkadii było odniesienie mitologicznego bóstwa Pan, z realnym władcą Toskanii, rodem Medyceuszy i zarządcą wszelkiego porządku na ziemi. Nado Naldi odniósł się wprost do Kosmy Medyceusza i do konkretnego miejsca - willa Careggia. Konkretne miejsce było pojemnikiem idei, nowej Arkadii obejmującej pałac i miasto ${ }^{51}$.

Norymberga i środowisko skupionych w tym mieście humanistów odnajdywało wzory włoskie, sam H. Schedel nie tylko gromadził literaturę rzymską i grecka, lecz także ją znał. Rozwinięty został wśród tutejszych humanistów swoisty synkretyzm ideowy, w którym antyk grecki, historia powstania Bizancjum był wzbogacony pamięcią czasów panowania rodów zwłaszcza Paleologów, gdzie wartości historyczne łączyły się z ideami mitów. Świat antyczny jako sacrosancta vetustas wnosiły do współczesności aktualizowaną stale memoria rozbudzając uczucia sentymentalne, czasem zabarwione melancholią przeszłości. Istotnymi zmianami, jakie pojawiają się w literaturze jest odmienne rozumienie pasterza. Wergiliański pasterz jest młody, wieśniaczy, rustykalny, w nowożytnej bukolice, np. w dziele Sannazaro jest starcem - mędrcem grającym na syryndze, a miejscem jest las, w którym rosną różne drzewa jako figury retoryczne, a nie realne, np. jodły, dęby, jesiony, platany, kasztany, topole, pinie, buki, lipy, tamaryszki, cyprysy, a nawet palmy. Wszystkie rosną razem w jednym gaju, a każde $\mathrm{z}$ nich wydaje refleksy światła i każde $\mathrm{z}$ nich roztacza odrębny zapach, cień, powiew wiatru. Drzewa są realne, choć rosną w świecie fikcji, jaką stanowi arkadia. Ujęcie krajobrazu w dziele Sannazaro

${ }^{50}$ Por. W. Kruss, Über die Stellung der Bukolik in ästhetischen Theorie des Humanismus, „Archiv für das Studium der Neueren Sprachen" 174 (1938) 180-198.

${ }^{51}$ Por. A. Hulubei, Naldo Naldi. Étude sur la joute de Julien et sur le bucoliques dédiées à Laurent de Médicis, „Humanisme et Renaissance” 3 (1936) 314. 
nie jest nowe, bo już wcześniej Petrarka stworzył analogiczne doświadczenia zmysłowe, przenosząc krajobrazy włoskie, których doświadczał na dworze papieskim w Awinionie, na ziemię Akwitanii.

Obrazy miast, ukazane w monumentalnym dziele przez H. Schedla, nie są planami realnymi ani mapami miast, ani nawet realnymi widokami. Nie są jednak makietami skojarzonymi z wyobrażeniami wotywnych miast trzymanych w dłoniach przez świętych. Nie są również literackimi greckimi arkadiami, zbyt dużo jest w nich historii, monumentalnych konkretów, choć otacza je życiodajna przyroda, w którą są wkomponowane. Realia historycznej przeszłości unaocznione w architekturze i monumentach, realia rzeki na pierwszym planie Konstantynopola, Bosfor i Morze Marmara, góry zamykające panoramę stanowią jako całość ramy dla sentymentalnej arkadii nowej. Przestrzeń jest zarazem terytorium, w którym usytuowano budowle nawiązujące do panowania cesarzy, przypominające czas przeszły, a zarazem rządzi całością nadrzędna idea. Jest nią pamięć memoria przekazana w wizji artystycznej. Jedynie widoczne na okręcie figurki ludzkie w mglisty sposób odsyłają do anonimowych wędrowców. Jeden z nich ubrany jest w strój zbliżony do ubioru zakonnego (dominikanin?). Zdobycie Konstantynopola i poddanie się miasta dynastii osmańskiej jest opisywane w badaniach historycznych jako tragedia, która dotknęła cały świat chrześcijański. Jednak zostały zachowane więzi handlowe, gospodarcze, pielgrzymki do Ziemi Świętej w XV w., które przestały być ruchem masowym, natomiast były realizowane przez bogatych kupców, feudałów, niektórych duchownych i bardzo zamożnych mieszczan. Uzmysławiały minioną historię miasta, które zdawało się dołączyć do losu Rzymu i Jerozolimy ${ }^{52}$.

Klasztor dominikanów w Perze był aktywnym centrum studiów i dyskusji w XIV w. Tron biskupi w Kaffie w latach 1391-1475 zajmowali dominikanie z Genui. Dlatego też dominikanie z Kaffy zakładali domy zakonne wzdłuż dróg w kierunku Podola, Mołdawii i Rusi. Zakonnicy i opaci wywodzili się z miejscowej ludności, co potwierdzają ich nazwiska i imiona: Szymon z Konstantynopola, bracia Chryzobergowie, Manuel Kalekas, Jan z Kastamonu ${ }^{53}$. Schyłek $\mathrm{XV}$ w. i kontakty na gruncie humanizmu religijnego oraz literackiego zacieśniały współpracę teologiczną z dominikanami, których teologiczne dysputy na bazie tomizmu i ścisłej logiki w budowaniu dowodu były podstawą zaufania odbiorców uznających konkrety. Wiąże się to nawet z faktem przyjęcia łacińskiego chrześcijaństwa przez cesarskiego kanclerza Demetriusza Kydonesa. Oddziaływanie było wzajemne, bowiem miało wspólne idee. Jedną z nich było dziedzictwo greckiej patrystyki, które legło u podłoża odradzania się i kształtowania neoplatonizmu renesansowego w 2. poł. XVI w. w Italii i w południowych księstwach niemieckich (dzisiejszej Bawarii, Austrii i Czech) oraz Polsce.

${ }^{52}$ Por. D. Jacoby, Pèlerinage médiéval et sanctuaires de Terre Sainte. La perspective vénitienne, w: tenże, Studies on the Crusader States and on Venetian Expansion, Northampton 1989, 56-89.

${ }^{53}$ Por. Balard, Laciński wschód XI-XV wiek, s. 428-429. 
Plany miast, które wykreślił lekarz i humanista z Norymbergi H. Schedel, wpisują się $\mathrm{w}$ głębokie tradycje średniowiecznych wyobrażeń urbs, znanych w malarstwie włoskim, które było dobrze znane naszemu autorowi. On sam nie był eklektykiem, znając literaturę szeroko pojętą - piśmiennictwo średniowieczne oraz najnowsze prądy literackie - był inspirowany duchem greckiej arkadii. Natomiast wyżej wspomniana literatura była adaptowana do nowego typu elit, wymagającego odbiorcy, żyjącego w konkretnej sytuacji religijnej, gospodarczej i politycznej Europy. Widok Konstantynopola, z jego kontekstem ówczesnej sytuacji, stanowi o indywiduum monumentów przypominających o chrześcijańskiej historii miasta. W analogiczny sposób stworzył widoki innych miast, w których jest suma wiedzy pisanej, historycznej, opisów oraz przeżyć, których dostarczała literatura ubogacona doświadczeniem własnych wędrówek. Stworzył summę wiedzy i eksperymentów całego zespołu wykonawców drzeworytników, wydawców, technologów, nawet mistrzów produkcji papieru. Idee są zaczepione w realiach nowoczesnej techniki i technologii, artystyczne wizje zrealizowało nader nowoczesne myślenie. Nie można wykluczyć nawiązania do realiów w widokach miast $\mathrm{z}$ konkretnymi budowlami, które jako monumenty pamięci historycznej stanowiły przedmiot doznań estetycznych. Pozostaje do szerszej analizy badawczej porównanie tekstów kunsztownych ekfraz, np. Psellosa, pisanych ku czci Konstantynopola, będących panegirykiem władców greckiej dynastii macedońskiej ${ }^{54}$. Już w tamtych czasach odrodził się ideał piękna greckiego zarówno w plastyce, jak i w literaturze. Te artystyczne synkretyzmy są licznie podejmowane w badaniach historycznych i literackich. Jak bardzo oddziaływały na twórców włoskich XV w., świadczy dzieło Florentyńczyka Masa Finiguerry - ilustrowana Kronika świata $\mathrm{z}$ roku 1460. Mistrz ukazał święta i festyny miast, wsparte tekstami liryk Piotra Bemba ${ }^{55}$. Michael Wolgemut ukazał widok Rzymu z roku 1493 (Rzym, Bilioteca Vaticana), który wskazuje się jako analogię z widokiem H. Schedla. Jednak w widoku Wolgemuta są znaczniejsze tendencje ożywienia widoku wiecznego miasta mieszkańcami i wędrowcami. Podobnie silniejsze tendencje łączące widok civitas i urbs wykazuje Erhard Reeuwich w swoim widoku Wenecji (Paryż, Bibliothèque Nationale de France) ${ }^{56}$.

$$
* * *
$$

Historia świata ukazana przez H. Schedla w duchu nowej antropologii, zaofiarowana jest odbiorcom uczonym, nieznanym, anonimowym, co wynika $\mathrm{z}$ istoty powielania drzeworytniczego, a więc zwielokrotnienia tych samych

\footnotetext{
${ }^{54}$ Szczególnie istotne są panegiryki Jana Geometresa oraz Psellosa opisujące w formie retorycznego, wzniosłego panegiryku ogrody imperialne. Por. Dagron, Constantinople imaginaire, s. 182nn.

${ }^{55}$ Por. A. Chastel, Italienische Renaissance. Die Ausbildung der Grossen Kunstzentren in der Zeit von 1460 bis 1500, München 1965, 5-6.

${ }^{56}$ Por. tamże, s. 107.
} 
obrazów. Jak bardzo zabiegał sam artysta o nowego odbiorcę świadczy jednoczesne wydanie dwóch wersji językowych - łacińskiej i niemieckiej. Należy upatrywać w zebranych widokach przekaz wiedzy historycznej, biblijnej i mitologicznej, co stało się nowym stylem przekazu wizji świata dla rodzącej się nowej oikumene europejskiej u progu nowożytności.

\section{THE PANORAMA OF CONSTANTINOPLE IN LIBER CHRONICARUM OF HARTMANN SCHEDEL (1493). THE IDEAL CITY - THE RECOLLECTION OF CHRISTIANITY}

\section{(Summary)}

The historical research of the illustrated Nuremberg Chronicle [Schedelsche Weltchronik (English: Schedel's World Chronicle)] of Hartmann Schedel comprises the complex historical knowledge about numerous woodcuts which present views of various cities important in the world's history, e.g. Jerusalem, Constantinople, or the European ones such as: Rome, some Italian, German or Polish cities e.g. Wrocław and Cracow; some Hungarian and some Czech Republic cities. Researchers have made a serious study to recognize certain constructions in the woodcuts; they indicated the conservative and contractual architecture, the existing places and the unrealistic (non-existent) places. The results show that there is a common detail in all the views - the defensive wall round each of the described cities. However, in reality, it may not have existed in some cities during the lifetime of the authors of the woodcuts. As for some further details: behind the walls we can see feudal castles on the hills shown as strongholds. Within the defensive walls there are numerous buildings with many towers typical for the Middle Ages and true-to-life in certain ways of building the cities. Schematically drawn buildings surrounded by the ring of defensive walls indicate that the author used certain patterns based on the previously created panoramic views.

This article is an attempt of making analogical comparisons of the cities in medieval painting. The Author of the article presents Roman mosaics and the miniature painting e.g. the ones created in the scriptorium in Reichenau. Since the beginning of $14^{\text {th }}$ century Italian painters such as: Duccio di Buoninsegna, Giotto di Bondone, Simone Martini and Ambrogio Lorenzetti painted parts of the cities or the entire monumental panoramas in various compositions and with various meanings. One defining rule in this painting concerned the definitions of the cities given by Saint Isidore of Seville, based on the rules which he knew from the antique tradition. These are: $u r b s$ - the cities full of architecture and buildings but uninhabited or civita - the city, the living space of the human life, build-up space, engaged according to the law, kind of work and social hierarchy. The tradition of both ways of describing the city is rooted in Italy. This article indicates the particular meaning of Italian painting in distributing the image of the city - as the votive offering. The research conducted by Chiara Frugoni and others indica- 
ted the meaning of the city images in the painting of various forms of panegyrics created in high praise of cities, known as laude (Lat.). We can find the examples of them rooted in the Roman tradition of mosaics, e.g. in San Apollinare Nuovo in Ravenna. They present both palatium and civitas. The medieval Italian painting, especially the panel painting, presents the city structure models which are uninhabited and deprived of any signs of everyday life. The models of cities - urbs, are presented as votive offerings devoted to their patron saints, especially to Virgin Mary. The city shaped as oval or sinusoidal rings surrounded by the defensive walls resembled a container filled with buildings. Only few of them reflected the existing cities and could mainly be identified thanks to the inscriptions. The most characteristic examples were: the fresco of Taddeo di Bartolo in Palazzo Publico in Siena, which presented the Dominican Order friar Ambrogio Sansedoni holding the model of his city - Siena, with its most recognizable building - the Cathedral dedicated to the Assumption of Mary. The same painter, referred to as the master painter of the views of the cities as the votive offerings, painted the Saint Antilla with the model of Montepulciano in the painting from 1401 for the Cathedral devoted to the Assumption of Mary in Montepulciano. In the painting made by T. di Bartolo, the bishop of the city of Gimignano, Saint Gimignano, presents the city in the shape of a round lens surrounded by defence walls with numerous church towers and the feudal headquarters characteristic for the city. His dummer of the city is pyramidally-structured, the hills are mounted on the steep slopes reflecting the analogy to the topography of the city. We can also find the texts of songs, laude (Lat.) and panegyrics created in honour of the cities and their rulers, e.g. the texts in honour of Milan, Bonvesin for La Riva, known in Europe at that time.

The city - Arcadia (utopia) in the modern style. Hartman Schedel, as a bibliophile and a scholar, knew the texts of medieval writers and Italian art but, as an ambitious humanist, he could not disregard the latest, contemporary trends of Renaissance which were coming from Nuremberg and from Italian cities. The views of Arcadia - the utopian city, were rapidly developing, as they were of great importance for the rich recipient in the beginning of the modern era overwhelmed by the early capitalism. It was then when the two opposites were combined - the shepherd and the knight, the Greek Arcadia with the medieval city. The reception of Virgil's Arcadia in the medieval literature and art was being developed again in the elite circles at the end of $15^{\text {th }}$ century. The cultural meaning of the historical loci, the Greek places of the ancient history and the memory of Christianity constituted the essence of historicism in the Renaissance at the courts of the Comnenos and of the Palaiologos dynasty, which inspired the Renaissance of the Latin culture circle. The pastoral idleness concept came from Venice where Virgil's books were published in print in 1470, the books of Ovid: Fasti and Metamorphoses were published in 1497 and Sannazaro's Arcadia was published in 1502, previously distributed in his handwriting since 1480. Literature topics presented the historical works as memoria, both ancient and Christian, composed into the images.

The city maps drawn by Hartmann Schedel, the doctor and humanist from Nurnberg, refer to the medieval images of urbs, the woodcuts with the cities, 
known to the author from the Italian painting of the greatest masters of the Trecenta period. As a humanist he knew the literature of the Renaissance of Florence and Venice with the Arcadian themes of both the Greek and the Roman tradition. The view of Constantinople in the context of the contemporary political situation, is presented in a series of monuments of architecture, with columns and defensive walls, which reminded of the history of the city from its greatest time of Constantine the Great, Justinian I and the Comnenus dynasty. Schedel's work of art is the sum of the knowledge written down or painted. It is also the result of the experiments of new technology. It is possible that Schedel was inspired by the hymns, laude, written by Psellos in honour of Constantinople in his elaborate ecphrases as the panegyrics for the rulers of the Greek dynasty - the Macedonians. Already in that time, the Greek ideal of beauty was reborn, both in literature and in fine arts. The illustrated History of the World presented in Schedel's woodcuts is given to the recipients who are educated and to those who are anonymous, in the spirit of the new anthropology. It results from the nature of the woodcut reproduction, that is from the way of copying the same images. The artist must have strived to gain the recipients for his works as the woodcuts were created both in Latin and in German. The collected views were supposed to transfer historical, biblical and mythological knowledge in the new way of communication.

Key words: Constantinople - the view of the city after 1453 - the reality, the history, the City as a votive offering, the city - the Arcadia (utopia)

Słowa kluczowe: Konstantynopol - widok miasta po 1453 r. - rzeczywistość, historia, miasto jako wotum ofiarne, miasto - Arkadia (utopia)

\section{BIBLIOGRAFIA}

\section{Źródła}

Villani Giovanns, Cronica, ed. G. Aquilecchia, w: Cronica [di] Giovanni i Villani, con le continuazioni de Matteo e Filippo, scelta, introduzione e note di G. Aquilecchia,

Nuova Universale Einaudi 159, Torino 1979.

IsIDORus HisPalensis, Etymologiae, PL 82, 73-728.

Schedel H., Liber chronicarum, Nuremberg 1493; wyd. niemieckie: Weltchronik, Nuremberg 1525.

Septuaginta czyli Biblia Starego Testamentu wraz z księgami deuterokanonicznymi i apokryfami, thum. ks. R. Popowski, Warszawa 2013.

\section{Opracowania}

BaLARD M., Laciński wschód XI-XV wiek, thum. W. Ceran, Kraków 2010.

Beccherucci L. - Brunetti G., Il Museo del'Opera del Duomo a Firenze, Milano 1970.

Berger A. - Bardill J., The Representations of Constantinople in Hartmann Schedel's World Chronicle, and Related Pictures, „Byzantine and Modern Greek Studies” 22 (1998) 3-29.

BiaŁostocki J., Sztuka XV wieku. Od Parlerów do Dürera, thum. G. Przewłocki, red. naukowa, aktualizacja i uzupełnienie bibliograficzne A. Ziemba, Warszawa 2010. 
Chastel A., Italienische Renaissance. Die Ausbildung der Grossen Kunstzentren in der Zeit von 1460 bis 1500, München 1965.

Dagron C., Constantinople imaginaire: études sur le recceil des „Patria”, Paris 1984.

FABIAŃSKI M., Złoty Kraków, Kraków 2010.

FonseCA C.D., La citta immaginata: dalla rappresentazione del mondo alla Gerusalemme celeste, w: Imago urbis. L'immagine della città nella storia d'Italia. Atti del convegno internazionale (Bologna 5-7 settembre 2001), a cura di F. Bocchi - R. Smurra, Bologna 2003.

Frugoni Ch., A Distant City. Images of Urban Experience in the Medieval World, Princeton 2009.

Frugoni Ch., L'Ytalia di Cimabue nella basilica superiore di Assisi. Uno squardo dal transetto alla navata, w: Imago urbis. L'immagine della città nella storia d'Italia. Atti del convegno internazionale (Bologna 5-7 settembre 2001), a cura di F. BocchiR. Smurra, Bologna 2003, 33-63.

Holtz W., Byzanz, Konstantinopel, Istambul. Handbuch der Kunstdenkmäler, Berlin 1971.

Huluber A., Naldo Naldi. Étude sur la joute de Julien et sur le bucoliques dédiées à Laurent de Médicis, „Humanisme et Renaissance” 3 (1936) 309-326.

J AcoBy D., Pèlerinage médiéval et sanctuaires de Terre Sainte. La perspective vénitienne, w: tenże, Studies on the Crusader States and on Venetian Expansion, Northampton 1989.

KREUER W., Imago civitatis: Stadtbildsprache des Spätmittelalters: Essener Bearbeitung der authentischen Stadtansichten aus der Schedelschen Weltchronik von 1493 mit 32 Vollfaksimilierungen des Orginals [sic] der Diözesan- und Dombibliothek Köln, Essener Geographische Schriften 2, Essen 1993.

Kruss W., Über die Stellung der Bukolik in ästhetischen Theorie des Humanismus, „Archiv für das Studium der Neueren Sprachen” 174 (1938) 180-198

MazURczak U., Geneza i rozumienie votum w kulturze europejskiej $i$ w tradycji chrześcijańskiej. Miasto jako votum dla Maryi i świętych, na wybranych przykładach malarstwa włoskiego, w: Zespót zabytkowy Piotrawina - promocja dziedzictwa. Materiały konferencji naukowej w Piotrawinie 2014, red. R. Bartnik, Lublin 2016, 77-98.

MazurcZaK U., Miasto w pejzażu malarskim XV wieku: Niderlandy, Lublin 2004.

Menegazzi L., Tomaso da Modena, Treviso 1979.

Orselli A.M., Tempo citta e simbolo fra tardoantico e alto medioevo, Bologna 2009.

PEIL D., Untersuchungen zur Staats- und Herrschaftsmetaphorik in literarischen Zeugnissen von der Antike bis zur Gegenwart, München 1983.

Popp D., Duccio und die Antike. Studium zur Antikenvorstellung und zur Antikenrezeption in der Sieneser Malerei am Anfang des 14. Jahrhunderts, München 1996.

Rucker E., Die Schedelsche Weltchronik. Das grosste Buchunternehmen der Durer Zeit, München 1985.

Schafer-Maisak P., Arkadien - Genese und Typologie einer idyllischen Wunschwelt, Frankfurt am Main - Bern 1981.

SChNeIDER A.M., Die Bevölkerung Konstantinopels im XV. Jahrhundert, Nachrichten der Akademie der Wissenschaften in Göttingen, Philologisch-Historische Klasse Nr. 9, Göttingen 1949. 


\section{ANEKS}

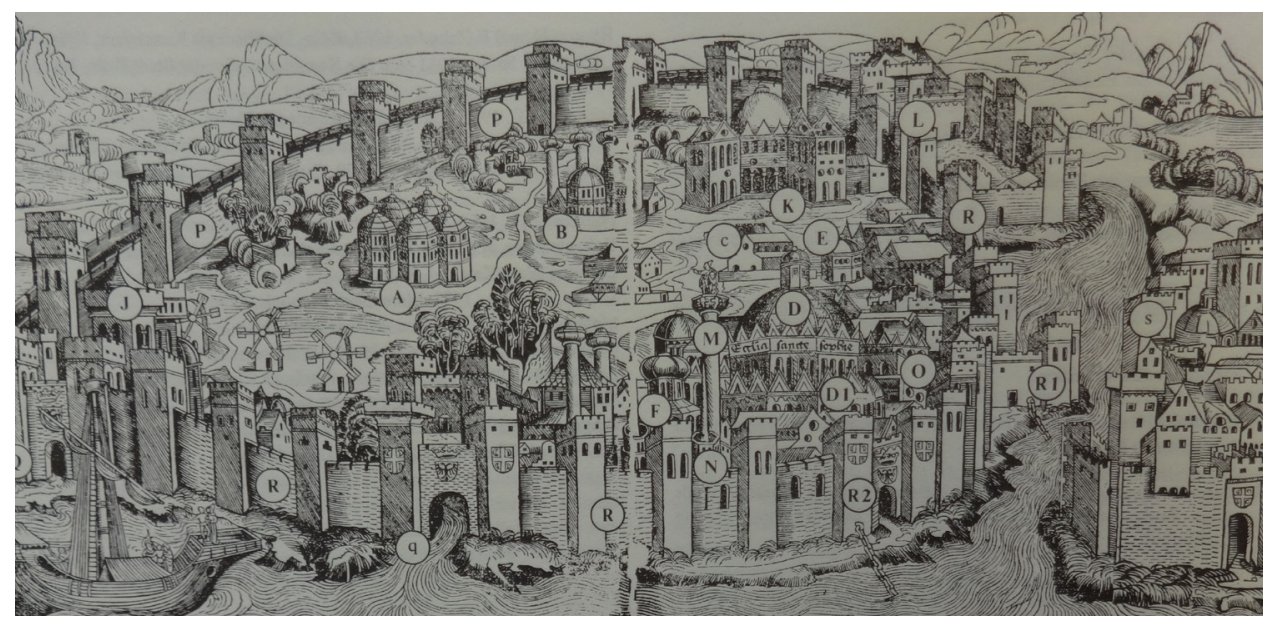

\section{Sakralbauten}

A. Die Pantokrator-Kirchen (Zeyrek Kilise Camii)

B. Die Pammakaristos-Klosterkirche (Fethiye Camii)

c. Basilika für die Armen. Christen

D. Die Hagia Sophia (Aya Sofya Müzesi)

D1. Baptisterium

E. Die Hagia Irene
F. Die Sergios und Bakchos-Kirche (Kücük Aya Sofya Camii)

G. Die Dominikanerkirche Sankt Paul (Arap Camii)

H. Die Sankt Georgskirche (Sen Jori Kilisesi)

\section{Profanbauten}

J. Burg der sieben Türme (Yedicule)

K. ,Juustinians Palast” (Tekfur Saray)
L. „Der Blachernenpalast”

M. Konstantinssäule (Cemberli tas)

N. Schlangensäule (Burma sütün)

O. Der Alte Saray (Topkapi Saray)

P. Die doppelte Landmauer

Q. Das Goldene Tor

R. Die Seemauer

R1. Saray-Spitze mit Sperrkette R2. „Seetor mit Sperrkette”

s. Die Befestigungsmauer von Pera (Galata)

\section{Konstantynopol:}

opis i rozpoznanie najważniejszych budowli, oznaczenia literowe i zasadnicze interpretacje wg W. Kreuera (W. Kreuer, Imago civitatis: Stadtbildsprache des Spätmittelalters, Essener Geographische Schriften 2, Essen 1993, 98) 
